\author{
Kamila PtazIŃSKA \\ Uniwersytet Pedagogiczny w Krakowie, Polska - Pedagogical University of Cracow, Poland \\ BOŻENA WóJTOWICZ \\ Krakowska Akademia im. Andrzeja Frycza Modrzewskiego, Polska - Andrzej Frycz Modrzewski Krakow \\ University, Poland
}

\title{
Dziedzictwo kulturowe Podkarpacia jako istotny element rozwoju przedsiębiorczości w regionie
}

\section{Cultural Heritage of Podkarpacie as an Important Element of Entrepreneurship Development in the Region}

Streszczenie: Województwo podkarpackie ze względu na swoje peryferyjne położenie na styku kultur, religii i tradycji, ma bardzo duży potencjał w zakresie dziedzictwa kulturowego. Bez wątpienia ważne dla rozwoju całego regionu są zyski generowane przez turystykę, dzięki którym m.in. istnieje możliwość renowacji zabytków znajdujących się na terenie województwa oraz wspierania lokalnych działań i przedsiębiorczości. Istotnymi produktami turystycznymi opierającymi się na dziedzictwie kulturowym są, oprócz zabytków materialnych, tzw. niematerialne elementy, które przez przedsiębiorcze zachowania ludzi stwarzają szansę na szybszy rozwój regionu. Dobrym przykładem promocji dziedzictwa regionu w zakresie zabytków, folkloru i tradycyjnych wyrobów są liczne przedsięwzięcia prowadzone przez władze województwa podkarpackiego. Dodatkowo należy podkreślić, iż wszystkie działania, które są podejmowane na rzecz rozwoju lokalnych społeczeństw przy wykorzystaniu zasobów dziedzictwa kulturowego, mają istotny wpływ na rozwój tzw. kapitału ludzkiego, który jest podstawą do rozwoju przedsiębiorczości. Głównym celem niniejszego opracowania jest ukazanie powiązań pomiędzy dziedzictwem kulturowym na Podkarpaciu a jego wpływem na przedsiębiorczość, a także odniesienie się do konkretnych przykładów dziedzictwa kulturowego, które przyczyniły się do rozwoju przedsiębiorczości. Do najważniejszych metod zastosowanych podczas realizowania tego zadania należy zaliczyć wnikliwą analizę literatury, przegląd danych statystycznych publikowanych przez GUS oraz liczne, bezpośrednie obserwacje przeprowadzone w terenie i wywiady nieustrukturyzowane.

\footnotetext{
Abstract: Because of its peripheral location at the crossroads of cultures, religions and traditions, the Podkarpackie voivodeship has great potential for cultural heritage. Undoubtedly important for the development of the whole region are the profits generated by tourism, thanks to which, among others, there is the possibility of restoration of monuments located in Podkarpackie voivodeship and support of local activities and entrepreneurship. Essential tourism products based on cultural heritage are, besides material monuments, so-called intangible elements which through the entrepreneurial behaviour of people, give the opportunity for faster development of the region. Numerous undertakings organised by the region authorities can be a very good example of promoting the heritage of the region in terms of monuments, but also folklore and traditional products. In addition, it should be emphasised that all activities that are undertaken for the development of local societies using the resources of cultural
} 
heritage have a significant impact on the development of the so-called human capital. The main objective of the study is to show the links between cultural heritage in Podkarpacie and its impact on entrepreneurship, as well as to refer to specific examples of cultural heritage that contributed to the development of entrepreneurship. The most important methods used during the implementation of this work include a thorough literature analysis, a review of statistical data published by the Central Statistical Office, as well as numerous direct field observations and unstructured interviews.

Słowa kluczowe: dziedzictwo kulturowe; przedsiębiorczość; turystyka kulturowa; województwo podkarpackie

Keywords: cultural heritage; cultural tourism; entrepreneurship; Podkarpackie voivodeship

Otrzymano: 2 listopada 2017

Received: 2 November 2017

Zaakceptowano: 28 maja 2018

Accepted: 28 May 2018

\section{Sugerowana cytacja/Suggested citation:}

Płazińska, K., Wójtowicz, B. (2018). Dziedzictwo kulturowe Podkarpacia jako istotny element rozwoju przedsiębiorczości w regionie. Przedsiębiorczość-Edukacja [Entrepreneurship-Education], 14, 282-291. DOI: $10.24917 / 20833296.14 .21$

\section{Wstęp}

Dziedzictwo kulturowe może mieć charakter uniwersalny lub regionalny. Zalicza się do niego w głównej mierze wytwory człowieka, które powstawały na przestrzeni wieków, a także te, które powstają obecnie i są szczególnie cenne dla danego miejsca. Dobry stan poszczególnych wytworów dziedzictwa kulturowego może świadczyć o znacznym przywiązaniu lokalnej ludności do wartości i historii zamieszkiwanego terenu, co wpływa na zachowanie i kształtowanie tożsamości regionalnej oraz na integrację społeczeństw.

Zasoby dziedzictwa kulturowego mają również istotny wpływ na rozwój turystyki, ponieważ poszczególne jego elementy stają się celami podróży wielu turystów, generujących dochód dla poszczególnych jednostek samorządu. Warto podkreślić, że podróżowanie $\mathrm{z}$ jednoczesnym obcowaniem $\mathrm{z}$ dziedzictwem kulturowym daje możliwość podziwiania świata przyrodniczego oraz dzieł sztuki, co wpływa na postrzeganie, myślenie oraz intelekt człowieka oraz kształtuje ład i harmonię (Midura, 2008).

W związku z tym zasadne wydaje się położenie większego nacisku na ochronę dziedzictwa kulturowego. Zachowanie i kultywowanie dziedzictwa powinno stanowić istotną część strategii rozwoju regionu pod względem turystycznym, gdyż daje dużą szansę na jego rozwój gospodarczy. Jest to szczególnie ważne w przypadku takich województw, jak województwo podkarpackie, które są uważane za biedne i zaliczane do tzw. Polski B. Szczególnymi produktami turystycznymi opierającymi się na dziedzictwie kulturowym, oprócz zabytków materialnych, są tzw. niematerialne elementy, do których należy zaliczyć cykliczne eventy, rzemiosło regionalne, kulturę, język oraz szlaki tematyczne. Niezwykle istotne w tym zakresie wydaje się być zwłaszcza zachowanie stabilności kulturowej, dzięki której zostanie utrzymana równowaga pomiędzy kulturą, ekologią a społeczeństwem i ekonomią na danym obszarze (Góral, 2013).

Głównym celem niniejszej pracy jest ukazanie powiązań pomiędzy dziedzictwem kulturowym na Podkarpaciu a jego wpływem na przedsiębiorczość w obszarze turystyki 
oraz wskazanie konkretnych przykładów dziedzictwa kulturowego, które zapoczątkowały rozwój przedsiębiorczości. Dodatkowo zaprezentowano istotę pojęcia dziedzictwa kulturowego oraz jego zakresu, a także dokonano próby wskazania miejsca dziedzictwa kulturowego wśród wielu czynników rozwoju lokalnego. Metody, które zostały wykorzystane, to wnikliwa analiza literatury oraz danych statystycznych, ponadto liczne bezpośrednie obserwacje w terenie i wywiady nieustrukturyzowane.

\section{Dotychczasowy stan badań oraz przegląd literatury}

Badania związane z dziedzictwem kulturowym w wybranych regionach są prowadzone od wielu lat, w tym na Podkarpaciu, gdzie to dziedzictwo jest niezwykle bogate. Niemniej jednak coraz częściej w literaturze przedmiotu jest mowa o połączeniu dziedzictwa kulturowego z przedsiębiorczością, w szczególności w kontekście turystyki, która dzięki niemu ma możliwość rozwoju na wybranych terenach. Połączenie dziedzictwa kulturowego z turystyką dało początek turystyce kulturowej, która coraz bardziej zyskuje na znaczeniu. W związku z tym powstało czasopismo branżowe „Turystyka Kulturowa” (www.turystykakulturowa.org/), w którym można znaleźć wiele artykułów traktujących o tych zagadnieniach. O specyfice niematerialnego dziedzictwa kulturowego i o jego ochronie pisali m.in. Jagusiewicz (2002), Jodełka (2005), Hoffman (2006), Maciejko (2009), Bartmiński (2013), Jasiewicz (2013). Warto zwrócić również uwagę na publikację Góral (2013), w której autorka przedstawia rolę samorządu terytorialnego w ochronie i kształtowaniu kulturalnego, niematerialnego dziedzictwa. O wykorzystaniu dziedzictwa kulturowego i połączeniu go z przedsiębiorczością pisała także Węglarska (2013), która niematerialne dziedzictwo kulturowe ujęła w kontekście marketingowym. O dziedzictwie kulturowym i o jego znaczeniu w rozwoju lokalnym pisali również Ritchie i Sins (1978) oraz Atkinson (2005). Warto również zwrócić uwagę na publikację Żegleń i Cisek (2007), gdzie autorki szeroko opisują możliwości, jakie niesie dziedzictwo kulturowe i przedsiębiorczość, połączone razem w postaci turystyki kulturowej, odnosząc się bezpośrednio do Podkarpacia. O dziedzictwie kulturowym powiązanym z przedsiębiorczością, renowacją tego dziedzictwa i możliwościach, jakie niesie jego odpowiednie zachowanie, pisała również Wojtkowiak (2009) na przykładzie dwóch podkarpackich zamków w Krasiczynie i Baranowie Sandomieskim.

\section{Charakterystyka województwa podkarpackiego}

Znajdujące się w południowo-wschodniej części Polski województwo podkarpackie ma wiele walorów turystycznych, wynikających z ukształtowania terenu, różnorodności fauny i flory oraz obecności dużych kompleksów leśnych. Cenne są również źródła wód mineralnych, dzięki czemu powstały tam liczne, jedne z najstarszych w Polsce uzdrowiska, takie jak np.: Iwonicz-Zdrój i Rymanów-Zdrój. Obszarami najczęściej odwiedzanymi przez różne grupy turystów są z pewnością Bieszczady wraz z jeziorem Solińskim, nazywanym również „morzem bieszczadzkim”. Warto wspomnieć ponadto o Beskidzie Niskim, który jest najbardziej naturalnym, nieprzekształconym przez człowieka pasmem górskim w Polsce. Dużą wartość przyrodniczą tych terenów podkreślono przez utworzenie Bieszczadzkiego oraz Magurskiego Parku Narodowego oraz wielu parków krajobrazowych. 
Województwo podkarpackie dzięki peryferyjnemu położeniu oraz swojej przeszłości historycznej ma znaczne walory kulturowe, często odmienne od walorów pozostałej części kraju, co czyni je unikatowymi. Warto wspomnieć także o dziedzictwie kulturowym pozostawionym przez Łemków i Bojków, którzy zamieszkiwali niegdyś bardzo licznie południową część województwa. Część tego dziedzictwa, tzn. dwa drewniane kościoły w Haczowie i Bliznem, ze względu na dużą wartość kulturową została wpisana na Listę światowego dziedzictwa UNESCO. Dziedzictwo kulturowe na Podkarpaciu można nawet nazwać wielowątkowym, gdyż przejawia się ono w wielu sferach od budownictwa aż po folklor.

\section{Dziedzictwo kulturowe Podkarpacia a przejawy przedsiębiorczości}

Podkarpacie to region o bardzo bogatym dziedzictwie kulturowym, będącym w większości pozostałością po mieszkających tam niegdyś ludziach. Część z tego dziedzictwa niestety traci swoją świetność i popada w ruinę, lecz dzięki przejawom przedsiębiorczości wielu osób istnieje realna szansa na zachowanie niektórych jego elementów.

Bardzo dobrym przykładem jest hotel Dwór Kombornia - luksusowy obiekt, który jeszcze na początku XXI w. odstraszał wyglądem i groził katastrofą budowlaną. Dwór w Komborni został wzniesiony w XVII w., kiedy to miejscowość ta była w rozkwicie i prężnie się rozwijała, natomiast po kolejnych zmianach właścicieli dwór zaczął popadać w ruinę. Nie mniej burzliwa była historia dworu po II wojnie światowej, kiedy to chciano cały obiekt przekazać Akademii Muzycznej w Warszawie, lecz uczelnia ta nie podjęła się opieki nad obiektem. W latach późniejszych teren wokół dworu został rozparcelowany. Przez pewien czas w obiekcie mieściła się szkoła rolnicza, po czym zamurowano częściowo otwory okienne i zamieniono to miejsce na magazyn zboża (ryc. 1).

Ryc. 1. Zabudowa Dworu Kombornia przed rewitalizacją - Hotel Wine Garden

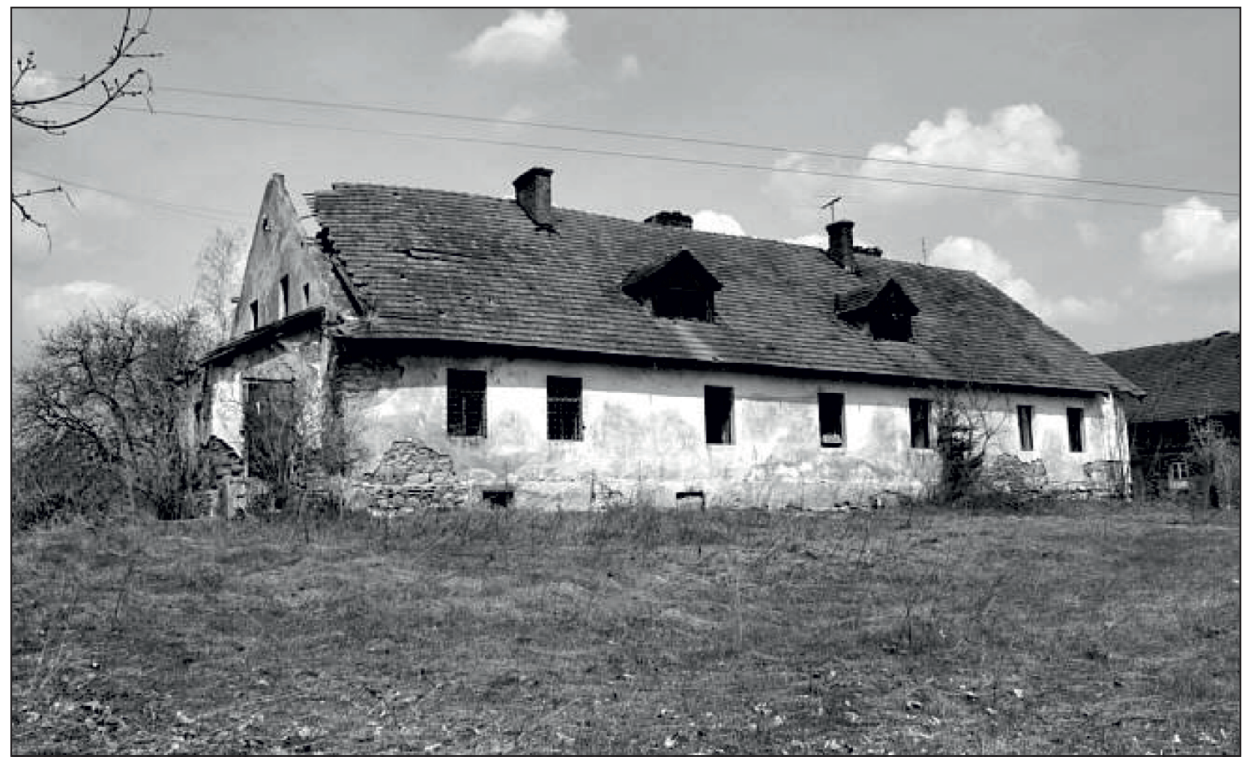

Źródło: https://zamki.res.pl/kombornia.php\#prettyPhoto 
W następnych latach dwór nadal zmieniał swoich właścicieli, którymi byli jeszcze Uniwersytet Jagielloński oraz firma Nowy Styl. Niestety, żaden z nich nie przywrócił świetności temu miejscu. Przełomowym okazał się rok 2007, kiedy to dwór przeszedł w prywatne ręce. Wtedy bardzo szybko zaczęły się w nim prace remontowe za zgodą konserwatora zabytków. Obecny właściciel, jak się szacuje, w renowację tego obiektu zainwestował kilkanaście milionów złotych. Jest to wartość szacunkowa, ponieważ sam właściciel, który obecnie pełni funkcję dyrektora hotelu Dwór Kombornia, nigdy nie ujawnił kosztów tej inwestycji. Pierwsi goście zostali przyjęci w listopadzie 2009 r., natomiast hotel rentowność z bieżącej działalności osiągnął zaledwie po czterech latach. W związku z tym zyski są notowane od 2013 r., przy średnim obłożeniu ok. 50\%, jak deklaruje właściciel obiektu. Cały kompleks obejmuje powierzchnię 10 ha, na których mieszczą się m.in.: czterogwiazdkowy butikowy Hotel SPA z bogatą infrastrukturą Wellness, Salon Win Karpackich, Centrum Konferencyjne i Bankietowe oraz komfortowy trzygwiazdkowy Hotel Wine Garden (ryc. 2).

Miejsce to zostało również odznaczone wieloma wyróżnieniami, w tym znakiem „Poziomki” przyznanym przez Magdę Gessler w roku 2015 i 2016. Dwór Kombornia jako jedyny obiekt z Podkarpacia znalazł swoje miejsce w pierwszej polskiej edycji przewodnika Gault \& Millau, który opisuje wyjątkowe hotele i regionalne specjały. Trzeba zaznaczyć w tym miejscu, że jest to wpływowa publikacja branżowa, uważana na całym świecie za tak samo ważną, jak słynna publikacja Michelin.

Kolejnym miejscem, które odniosło sukces dzięki wykorzystaniu zastanego dziedzictwa kulturowego, jest znajdująca się koło Przemyśla wioska tematyczna „Kuńkowce”. Jest ona przykładem ciekawej i stosunkowo nowej idei łączącej dziedzictwo kulturowe, wioskę

Ryc. 2. Zabudowa Dworu Kombornia po rewitalizacji - Hotel Wine Garden

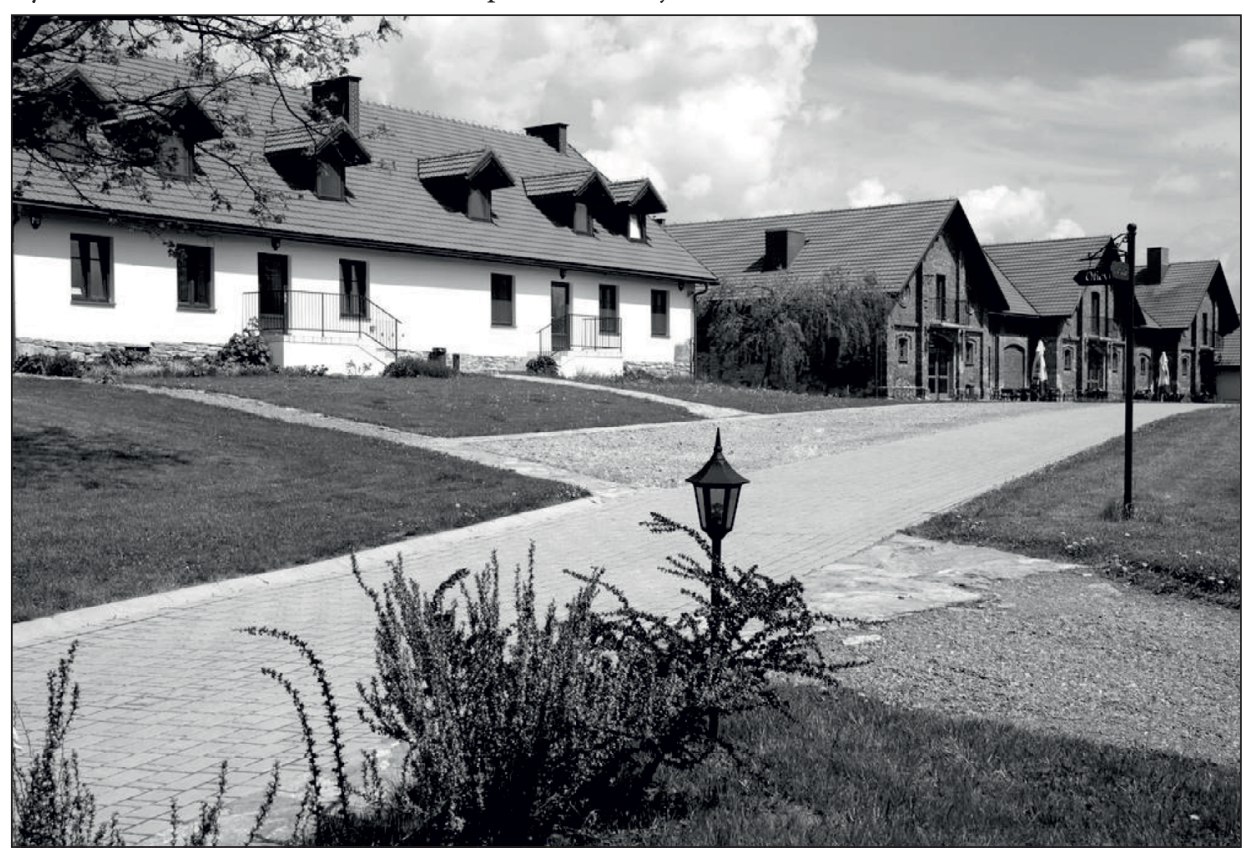

Źródło: https://www.booking.com/hotel/pl/dwaor-komboria-pokoje-goscinne.pl.html 
tematyczną z lokalną przedsiębiorczością. Przy okazji jest to dobry sposób na znalezienie miejsca dla lokalnego społeczeństwa w zmieniającej się gospodarce. Powstała ona z inicjatywy lokalnej społeczności, która chciała wykorzystać niszczejące fragmenty dawnego grodu, znajdującego się przed wiekami w Kuńkowcach. Pomysł powstania wioski fantasy w tym miejscy zrodził się najpierw w głowach młodych ludzi, interesujących się właśnie tą tematyką, którzy postawili sobie za cel realizację projektu pt.: „Kuńkowce - Wioska Fantasy”. Główną ideą przyświecającą twórcom było ożywienie dziedzictwa kulturowego na tym terenie, aktywizacja i integracja miejscowej młodzieży i dorosłych, a także możliwość zarobienia dodatkowych pieniędzy. W związku z tym, przy wykorzystaniu w dużej mierze funduszy unijnych, wybudowano replikę średniowiecznej osady obronnej. Obecnie miejsce to ma bogatą ofertę skierowaną do turystów indywidualnych, grup szkolnych, a nawet - turystów biznesowych. Właściciele wioski w wielu wywiadach mówią, że jedyną rzeczą, która zabijała w nich przedsiębiorczość podczas realizowania projektu „Kuńkowce - Wioska Fantasy”, była wszechogarniająca ich biurokracja, gdyż pozyskiwanie samych zezwoleń i innych dokumentów, które były niezbędne do rozpoczęcia budowy, trwało dużej niż sama budowa i wykończenie wioski. Obecnie w tym miejscu znajdują się drewniany fort z dwiema bramami oraz sześcioma wieżami, karczma i dziewięć chat różnej wielkości. Ponadto dla turystów przygotowano staw z rybami oraz ziemiankę z piecem do grzania wody. Jak podkreślają właściciele, inwestycja jeszcze nie przynosi dochodów, ponieważ odwiedzają ją głównie turyści z Podkarpacia, ale przy większej promocji ma ona szansę na większe zainteresowanie ze strony odwiedzających, a co za tym idzie - na relatywnie wysokie zyski.

Interesującym przykładem wykorzystania dziedzictwa kulturowego jest atrakcja o nazwie Bieszczadzkie Drezyny Rowerowe, która powstała w 2015 r. Pomysł na szlak pokonywany drezynami zrodził się w głowie lokalnego przedsiębiorcy w 2013 r., kiedy przestała być użytkowana linia kolejowa numer 108, która działała nieprzerwanie od 1872 r., czyli od czasów panowania na tym terenie władz Cesarstwa Austrii. Linia ta, łącząca Stróże z przejściem granicznym w Krościenku, została wyłączona z użytku ze względu na brak rentowności. Wtedy to miejscowy przedsiębiorca Janusz Demkowicz postanowił ożywić to dziedzictwo kulturowe w postaci historycznej linii kolejowej i stworzył ówcześnie bezapelacyjnie jedną z największych atrakcji Bieszczadów - Bieszczadzkie Drezyny Rowerowe. Udostępniona dla turystów trasa wycieczkowa liczy około $47 \mathrm{~km}$. Drezyny są napędzanie tylko i wyłącznie siłą ludzkich nóg (ryc. 3). Wypożyczalnia drezyn i główna stacja znajdują się w Uhercach Mineralnych. Druga stacja, która działa tylko w sezonie letnim, znajduje się w Ustrzykach Dolnych. Wszystkie drezyny rowerowe na trasę wyjeżdżają wspólnie, nie ma możliwości wyjechania drezyną indywidualnie, ponieważ wszystkie drezyny podczas przejazdu podlegają kierownikowi składu, który zawsze jedzie w pierwszej $\mathrm{z}$ nich.

Wynika to $\mathrm{z}$ tego, że trasa przejazdu przecina często ruchliwe $\mathrm{w}$ sezonie drogi, w związku z czym, gdy drezyny zbliżają się do jednej z nich, musi ona zostać chwilowo zamknięta, tak aby wszystkie drezyny przejechały bezpiecznie. W pierwszym roku swojej działalności z tej atrakcji skorzystało ponad 30 tys. turystów, a w kolejnych latach - ponad 50 tys. Właściciel Bieszczadzkich Drezyn Rowerowych zachęca lokalnych mieszkańców do wykazywania postaw przedsiębiorczych przez chociażby korzystanie $\mathrm{z}$ atrakcji, którą stworzył: „Jest to pierwsza tego typu atrakcja w Polsce. Zachęcamy też mieszkańców wsi położonych wzdłuż przejazdu drezyn do organizowania tradycyjnego poczęstunku dla 
Ryc. 3. Bieszczadzkie Drezyny Rowerowe

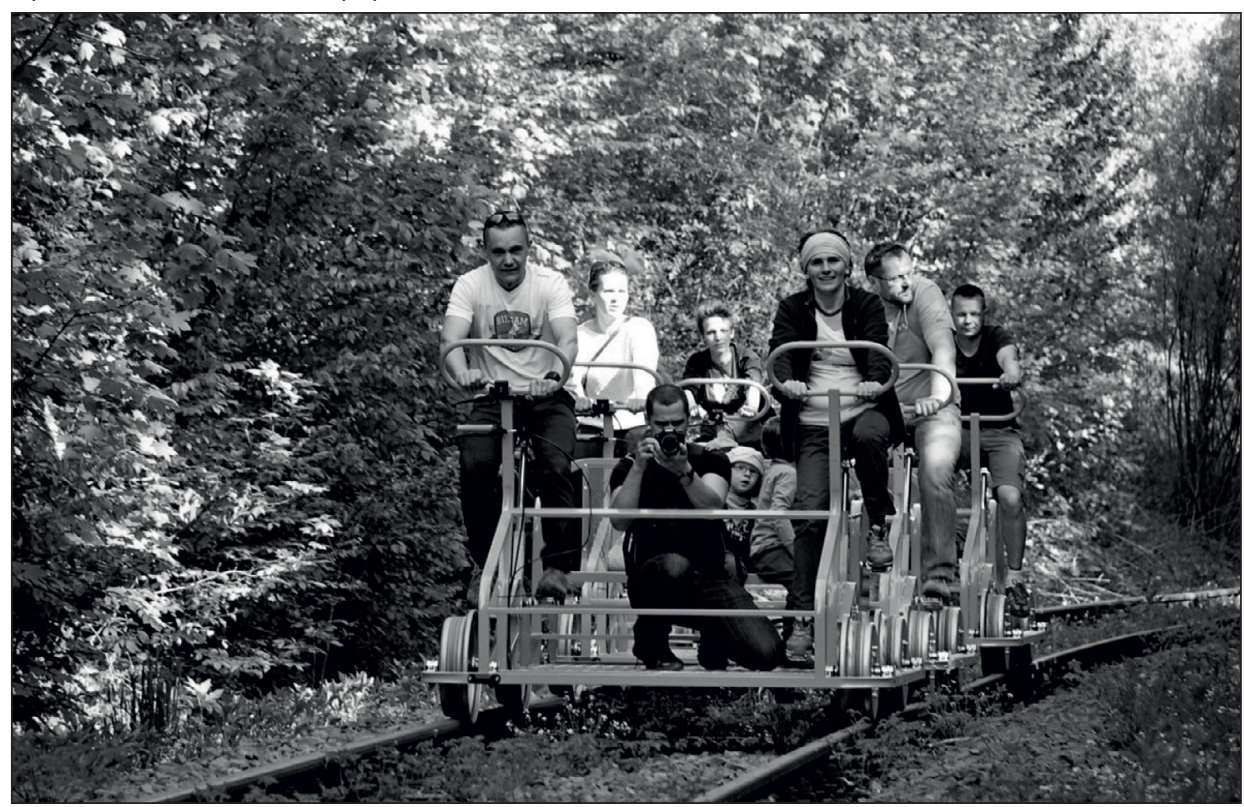

Źródło: http://bgtk.pl/gallery/bieszczadzie-drezyny-rowerowe/

turystów. Nie żadne napoje gazowane i batony, ale kompot, swojski chleb z ogórkiem kiszonym albo pyszne ciasto domowe. I tak wokół drezyn tworzą się kolejne atrakcje oraz... miejsca pracy" (www.biznesistyl.pl). Ogromnym wyróżnieniem dla twórcy tej atrakcji, która wykorzystuje znamienicie dziedzictwo kulturowe, było wyróżnienie przyznane przez Polską Organizację Turystyczną w 2015 r. dla Bieszczadzkich Drezyn Rowerowych jako najlepszego produktu turystycznego $2015 \mathrm{r}$.

\section{Podsumowanie}

W związku z bardzo bogatymi zasobami dziedzictwa kulturowego na Podkarpaciu istnieje możliwość rozwoju lokalnych inicjatyw, a także przedsiębiorczości. Dzięki kreatywności niektórych osób w miejscach, które zostały spisane na starty, powstają przepiękne hotele, ciekawe wioski tematyczne oraz inne atrakcję przyciągające mnóstwo turystów i generujące w ten sposób zyski. Jak się okazuje, przykład Dworu w Komborni, wioski tematycznej w Kuńkowcach czy Bieszczadzkich Drezyn to tylko część tego, jak dziedzictwo kulturowe jest wykorzystywane do rozwoju przedsiębiorczości. Trzeba też podkreślić, iż dzięki tym przedsięwzięciom, podejmowanym przez lokalnych przedsiębiorców, dziedzictwo to otrzymuje drugie życie i nie popada w ruinę i zapomnienie. Ponadto liczne przedsięwzięcia organizowane przez władze województwa podkarpackiego mogą być bardzo dobrym przykładem na promocję dziedzictwa regionu w zakresie zabytków, folkloru i tradycyjnych wyrobów. Dodatkowo należy podkreślić, iż wszystkie działania, które są podejmowane na rzecz rozwoju lokalnych społeczeństw przy wykorzystaniu zasobów dziedzictwa kulturowego, mają istotny wpływ na rozwój tzw. kapitału ludzkiego oraz wytworzenie silniejszej tożsamości związanej z kulturą danego obszary (Czerwińska, 
2015). Niezwykle ważne wydaje się również w dzisiejszych czasach to, aby wspierać lokalne tradycje, zwyczaje i zabytki tak, aby nie zniknęły we wszechobecnej kulturze masowej i nadal były wizytówką regionu, ponieważ warto podkreślić, iż dziedzictwo kulturowe to nie tylko to, co powstało w przeszłości, ale także to, co powstaje obecnie przez działania człowieka i jego przedsiębiorcze postawy. Można zatem stwierdzić, iż dziedzictwo kulturowe jest bardzo dobrym początkiem do rozwoju przedsiębiorczości, gdyż jednym z warunków, który jest niezbędny przy wprowadzaniu zmian i rozwoju przedsiębiorczości, jest podniesienie konkurencyjności na danym terenie.

\section{Literatura \\ References}

Atkinson, D. (2005). Heritage. W: D. Atkinson (red.), Cultural geography. Londyn: I.B. Tauris.

Bartmiński, J. (2013). Specyfika niematerialnego dziedzictwa kulturowego - problemy ochrony, dokumentacji i „rewitalizacji”. W: J. Adamowski, K. Smyk (red.), Niematerialne dziedzictwo kulturowe: źródła - wartości - ochrona. Lublin - Warszawa: Wydawnictwo UMCS, 35-51.

Czerwińska, K. (2015). Dziedzictwo kulturowe Śląska Cieszyńskiego jako istotny element strategii turystycznej regionu. Turystyka Kulturowa, 1, 6-16.

Faryna-Paszkiewicz, H., Omilanowska, M., Pasieczny, R. (red.). (2001). Atlas zabytków architektury $w$ Polsce, Warszawa: Wydawnictwo Naukowe PWN.

Gieron, A. (2017, 10 października). Kolej na Magdę i Janusza. Bieszczadzkie Drezyny Rowerowe. Biznes i Styl. Pozyskano z: www.biznesistyl.pl/ludzie/sylwetki/4200_kolej-na-magde-i-janusza.-bieszczadzkie-drezyny-rowerowe!.html

Główny Urząd Statystyczny (2012). Rocznik Statystyczny Województw. Warszawa.

Góral, A. (2013). Rola samorządu terytorialnego w zrównoważonym zarządzaniu niematerialnym dziedzictwem kulturowym. W: J. Adamowski, K. Smyk (red.), Niematerialne dziedzictwo kulturowe: źródła - wartości - ochrona. Lublin - Warszawa: Wydawnictwo UMCS, 99-110.

Hoffman, B. (2006). Art and Cultural Heritage: law, policy and practice. Cambridge: Cambridge University Press.

Jagusiewicz, A. (2002). Dziedzictwo kulturowe w turystyce polskiej. Problemy Turystyki, 3(4), 105-117.

Jasiewicz, Z. (2013). Przedmiot i funkcje Konwencji o ochronie niematerialnego dziedzictwa kulturowego. Spojrzenie etnologa. W: J. Adamowski, K. Smyk (red.), Niematerialne dziedzictwo kulturowe: źró-

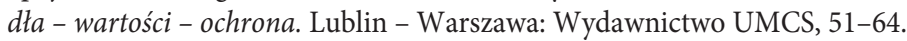

Jodełka, H. (2005). Międzynarodowa ochrona niematerialnego dziedzictwa kulturowego. Stosunki Międzynarodowe - International Relations, 3-4, 141-160.

Kulczyk, S. (2014). Atrakcyjność turystyczna krajobrazu - przykład podejścia systemowego. Turystyka Kulturowa, 4, 6-15.

Maciejko, W. (2009). Prawny obowiązek poszanowania dziedzictwa kulturowego. W: B. Chammas (red.), Ochrona środowiska, turystyka i dziedzictwo kulturowe Pogórza Dynowskiego. Dynów: Związek Gmin Turystycznych Pogórza Dynowskiego, 26-31.

Midura, F. (2009). Dziedzictwo kulturowe elementem ożywienia ruchu turystycznego na wsi. W: B. Chammas (red.), Ochrona środowiska, turystyka i dziedzictwo kulturowe Pogórza Dynowskiego. Dynów: Związek Gmin Turystycznych Pogórza Dynowskiego, 33-42.

Mokras-Grabowska, J. (2009). Możliwości rozwoju turystyki kulturowej obszarów wiejskich w Polsce. Turystyka Kulturowa, 1, 14-31.

Nowiński, K. (2001). Najciekawsze zabytki w Polsce - przewodnik. Warszawa: Muza SA.

Orzechowska-Kowalska, K., Kowalski, R. (2006). Wybrane aspekty ochrony dziedzictwa kulturowego w kontekście turystyki. W: J. Krupa, J. Biliński (red.), Turystyka w badaniach naukowych. Prace przyrodnicze i humanistyczne. Rzeszów: Wyższa Szkoła Informatyki i Zarządzania, 56-71. 
Pabian, B. (2006). Atrakcje turystyczne Polski. Walory kulturowe. Warszawa: Wydawnictwo WSHiT.

Płazińska, K. (2015). Raport z analizy potencjału turystyczno-kulturowego powiatu jasielskiego. Turystyka Kulturowa, 12, 73-85.

Ritchie J.R., Sins M. (1978). Culture as Determinant of Attractiveness. W: Annals of Tourism Research, April-June, 252-267.

Werczyński, D. (2014). Skansen jako produkt turystyczny. Analiza wybranych przykładów. Zeszyty Naukowe. Turystyka i Rekreacja, 1/13, 157-177.

Węglarska, K. (2013). Niematerialne dziedzictwo kulturowe w kontekście marketingowym - szanse i zagrożenia. W:J. Adamowski, K. Smyk (red.), Niematerialne dziedzictwo kulturowe: źródła - wartości ochrona. Lublin - Warszawa: Wydawnictwo UMCS, 89-97.

Wieszaczewska, A. (2015). Szlak Tradycyjnego Rzemiosła Podkarpacia jako szansa na rozwój turystyki kulturowej w regionie. Turystyka Kulturowa, 2, 36-46.

Wojtkowiak, A. (2008). Atrakcje turystyczne Podkarpacia na przykładzie renesansowych zamków w Krasiczynie oraz Baranowie Sandomierskim. W: Ochrona środowiska, turystyka i dziedzictwo kulturowe Pogórza Dynowskiego: V Konferencja Naukowo-Techniczna „Błękitny San”, materiały pokonferencyjne.

Załącznik do uchwały nr XLIV/845/10 Sejmiku Województwa Podkarpackiego z dnia 29 marca 2010, Wojewódzki program opieki nad zabytkami w województwie Podkarpackim na lata 2010-2013, Urząd Marszałkowski województwa podkarpackiego, departament edukacji i kultury, Rzeszów.

Żegleń, P., Cisek, B. (2007). Analiza rozwoju turystyki w województwie podkarpackim w kontekście rozwoju turystyki w Polsce i na świecie. Rzeszów: Wojewódzki Urząd Pracy w Rzeszowie.

Kamila Płazińska, mgr geografii, absolwentka Uniwersytetu Pedagogicznego im. KEN w Krakowie, obecnie $\mathrm{w}$ trakcie studiów doktoranckich również na tej uczelni. Tematy badawcze, którymi się zajmuje, to m.in.: turystyka kulturowa, turystyka biznesowa, enoturystyka oraz inne formy spędzania wolnego czasu $\mathrm{z}$ wykorzystaniem walorów turystycznych. W związku z zainteresowaniem turystyką aktywnie związana z branżą turystyczną. Autorka ponad 20 artykułów naukowych z zakresy turystyki, uczestniczka licznych konferencji naukowych zarówno międzynarodowych, jak i krajowych.

Kamila Płazińska, MA, graduate of Geography at the Pedagogical University of Cracow, currently a $\mathrm{PhD}$ student at this university. Her research topics include cultural tourism, business tourism, enotourism and other leisure activities based on tourist values. Due to the profile of tourism interest, she is actively associated with tourism industry. She is the author of more than 20 articles on tourism, a participant of numerous international and national conferences.

\section{Adres/Address;}

Uniwersytet Pedagogiczny im. Komisji Edukacji Narodowej w Krakowie

Instytut Geografii

Zakład Dydaktyki Geografii

ul. Podchorążych 2

30-084 Kraków, Polska

e-mail: kamila.plazinska@gmail.com

Bożena Elżbieta Wójtowicz, prof. nadzw. na Wydziale Prawa, Administracji i Stosunków Międzynarodowych Krakowskiej Akademii im. Andrzeja Frycza Modrzewskiego. Jej zainteresowania naukowo-badawcze i tematyka ponad 240 publikacji naukowych koncentrują się wokół problemów turystyki międzynarodowej, turystyki kulturowej i rekreacji oraz współczesnych problemów środowiska przyrodniczego i zagadnień z zakresu dydaktyki geografii. Referentka na ponad 130 konferencjach krajowych i zagranicznych. 
Bożena Elżbieta Wójtowicz, professor at the Faculty of Law, Administration and International Relations of the Andrzej Frycz Modrzewski Krakow University. Research interests and the subject matter of more than 240 publications focus on issues of international tourism, cultural tourism and recreation, contemporary environmental problems and issues of didactics of geography. A speaker at more than 130 national and international conferences.

\section{Adres/Address:}

Krakowska Akademia im. Andrzeja Frycza Modrzewskiego

Wydział Prawa, Administracji i Stosunków Międzynarodowych

ul. Gustawa Herlinga-Grudzińskiego 1

30-705 Kraków, Polska

e-mail: boz.wojt@gmail.com 